\title{
Effect of different growth parameters on endoglucanase enzyme activity by bacteria isolated from coir retting effluents of estuarine environment
}

\author{
${ }^{*}$ G. Immanuel, R. Dhanusha, P. Prema and A. Palavesam
}

\author{
Marine Biotechnology Division, Centre for Marine Science and Technology, M. S. University, Rajakkamangalam, \\ Kanyakumari District, Tamilnadu, India
}

Received 18 October 2005;

revised 7 February 2006;

accepted 1 March 2006

available online 18 April 2006

\begin{abstract}
The cellulolytic enzyme-endoglucanase activity against coir fibre, a major biowaste by bacteria such as Cellulomonas, Bacillus and Micrococcus spp. isolated from coir retting effluents of estuarine environment was studied. The enzyme assay was carried out by using various concentrations $(0.5-2 \%)$ of substrate of coir powder as a carbohydrate in different $\mathrm{pH}(5-9)$ and temperature $\left(20-50{ }^{\circ} \mathrm{C}\right)$. The enzyme activity was minimum in $0.5 \%$ substrate concentration at lower pH $5(0.0087,0.0143$ and $0.0071 \mathrm{U} / \mathrm{mL})$ and at $20{ }^{\circ} \mathrm{C}$ temperature $(0.0151,0.0154$ and $0.0122 \mathrm{U} / \mathrm{mL})$ by the bacterial strains such as Cellulomonas, Bacillus and Micrococcus spp respectively. Then this level was increased and reached maximum at the neutral $\mathrm{pH}(0.0172,0.0165$ and $0.0121 \mathrm{U} / \mathrm{mL})$ and at $40{ }^{\circ} \mathrm{C}(0.0336,0.0196$ and $0.0152 \mathrm{U} / \mathrm{mL})$ by the selected bacterial species. Further increase of $\mathrm{pH}$ and temperature, the enzyme activity reduced considerably to $0.0083,0.0143$ and $0.0037 \mathrm{U} / \mathrm{mL}$ at $\mathrm{pH} 9$ and $0.0154,0.0197$ and $0.0121 \mathrm{U} / \mathrm{mL}$ at $50{ }^{\circ} \mathrm{C}$ by the tested bacterial strains. The same trend was also obtained in oth er substrate concentrations such as 1.0, 1.5 and $2.0 \%$. With in the four substrate concentrations, the endoglucanase enzyme activity was more in $1.5 \%$ concentration at the tested $\mathrm{pH}$ and temperatures. From the over all result, it was observed that, among the three bacterial strains, the enzyme activity was more in Cellulomonas sp, followed by Bacillus and Micrococcus spp. in varying $\mathrm{pH}$ and temperature.
\end{abstract}

Key words: Cellulolytic enzyme, Endoglucanase, coir retting effluent, Cellulomonas, Bacillus, Micrococcus

*Corresponding Author, E-mail: g_immas@yahoo.com

\section{INTRODUCTION}

Cellulose is probably the most abundant biological compound on terrestrial earth. It is the dominant waste material from agriculture industry in the form of stalks, stems and husk and is one of the most abundant renewable sources. By means of chemical or bioconversion methods, it is possible to transform this insoluble polymer into glucose, an excellent substrate for industrial fermentation. Mainly bacteria, fungi and actinomycetes achieve bioconversion of these materials. Several studies were carried out to produce cellulolytic enzymes in biowaste degradation process by several microorganisms including fungi such as Trichoderma sp., Penicillium sp., Aspergillus spp. respectively by Mandels (1975), Hoffman and Wood (1985), Brown et al. (1987), Lakshmikant and Mathur (1990) etc. Similarly cellulolytic property of bacterial species like Pseudomonas, Cellulomonas, Cellulovibrio and Sporocytophaga spp. was also reported (Nakamura and Kappamura, 1982). The specific cellulolytic activity shown by the bacterial species is found to be depending on the source of occurrence (Sexana et al., 1993). The cellulase system of the mesophilic cellulolytic aerobe,
Cellulomonas fimi is one of the first studied and has since been one of the most studied bacterial cellulase systems (Whittle et al., 1982; O’Neill et al., 1986; Shen et al., 1995). Many spore-forming bacteria have been isolated from factors that have a feedstock from cattle waste (Sharma and Hobson, 1985), cow manure (Palop et al., 1989), woody biomass (Sleat and Mah, 1984), municipal solid waste (Cailliex et al., 1992) etc. Similarly many strains of cellulolytic anaerobic bacteria have been reported from various sources as human colon (Skinner, 1960), estuarine sediments (Madden, et al., 1982), freshwater sediments (Leschine and CanaleParola, 1983), decomposing vegetation (Madden, 1983; Petidemange et al., 1984). Because of the common occurrence of these bacteria in various natural environments, they are responsible for vast amount of cellulose. Cellulase yields appear to depend on a complex relationship involving a variety of factors like inoculum size (Carbon source and cellulose quality), $\mathrm{pH}$ value, temperature, presence of inducers, medium additives, aeration and growth time etc. The particle size of cellulose can affect cellulase production by microorganisms (Greaves, 1971). Release 
of enzyme is directly proportional to the particle size of the substrate used, i.e. release of enzyme increases, when the particle size of the substrate decreases. Thus attention has been focused to study the cellulolytic activity and cellulase enzyme production by several microorganisms in various products as well as in various environments. Attempts to increase the production of cellulose enzymes from bacteria including several processes like mutation (Stewart and Leatherwood, 1976; Haggett et al., 1978), protoplast fission (Gokhale et al., 1984), optimization of medium composition and environmental factors (Prasetsan and Doelle, 1987) etc have also been made. The bioconversion of various complex cellulosic waste materials such as bagasse (Kansoh et al., 1999), corncob (Ojumu et al., 2003) and saw dust (Solomon et al., 1999) have been reported. Coir dust and fibres are also major biowastes of coir industries of India, discarded along with coir retting effluent to estuarine environment. Yet literature related to the coir fibre as a carbohydrate source and cellulolytic activity by microorganisms involved in coir retting process is not studied. Hence in the present study, the endoglucanase enzyme activity of bacteria like Cellulomonas, Bacillus and Micrococcus spp. associated with coir retting process against these polymers were studied with varying environmental factors such as $\mathrm{pH}$ and temperature. This work have carried out this work during September 2004 to May 2005 in the Department of Marine Microbiology as well as Marine Biotechnology, Centre for Marine Science and Technology in India.

\section{MATERIALS AND METHODS}

Coir retting effluent collection and carbohydrate sample preparation

The substrate used for this study was coconut fibre powder collected from coir retting industries in Rajakkamangalam area of K. K. District, South India. The substrate was sun dried for few days to reduce the moisture content and pretreated as described by Gharpuray et al., (1983). The resulted powdery material was used as a carbohydrate source. The coir retting effluent was collected aseptically from the discharging point of Rajakkamangalam estuarine environment in sterile bottles with proper cooling for bacterial isolation. The collected effluent samples were then brought to the laboratory and stored at $4{ }^{\circ} \mathrm{C}$ for further studies.

\section{Isolation and identification of cellulose degrading} bacteria

$1 \mathrm{~mL}$ of coir retting effluent sample was inoculated into 100 mL of Berg's medium ( $\mathrm{NaNO}_{3} 2 \mathrm{~g} / \mathrm{L}, \mathrm{MgSO}_{4} 0.5$ $\mathrm{g} / \mathrm{L}, \mathrm{K}_{2} \mathrm{HPO}_{4} 0.05 \mathrm{~g} / \mathrm{L}, \mathrm{Fe}_{2} \mathrm{SO}_{4} 0.01 \mathrm{~g} / \mathrm{L}, \mathrm{CaCl}_{2} 0.02 \mathrm{~g} / \mathrm{L}$, $\mathrm{MnSO}_{4} 0.02 \mathrm{~g} / \mathrm{l}, \mathrm{pH} 7$ ) in a $250 \mathrm{~mL}$ conical flask and incubated at $30^{\circ} \mathrm{C}$ for 5 days with constant shaking and $1 \mathrm{~mL}$ of this culture broth was inoculated in the same manner. This culture was repeated for 3 times and then the culture broth was spreaded on Berg's agar plates $(0.1 \mathrm{~mL})$. The cellulolytic organisms were isolated by overlying plates with cellulose paper (Whatman No: 1) as carbon source. The cellulolytic organisms were identified by the appearance of yellow colour colonies over the filter paper. The same type of yellow colour colonies were streaked on Carboxy Methyl Cellulose (CMC) agar plates $\left(\mathrm{NaNO}_{3} 2 \mathrm{~g} / \mathrm{L}, \mathrm{MgSO}_{4} 0.5 \mathrm{~g} / \mathrm{L}, \mathrm{K}_{2} \mathrm{HPO}_{4}\right.$ $0.05 \mathrm{~g} / \mathrm{L}, \mathrm{Fe}_{2} \mathrm{SO}_{4} 0.01 \mathrm{~g} / \mathrm{L}, \mathrm{CaCl}_{2} 0.02 \mathrm{~g} / \mathrm{L}, \mathrm{MnSO}_{4} 0.02 \mathrm{~g} /$ L, CMC 1\%, Agar 2\%, pH 7) and incubated for $24 \mathrm{~h}$ at 30 ${ }^{\circ} \mathrm{C}$. The isolated colonies on these plates were maintained on CMC agar slants at $4^{\circ} \mathrm{C}$ for further analysis.

\section{Screening of cellulase activity}

The isolated bacterial colonies were further characterized for their morphological and biochemical characters as described by (Cappuccino and Sherman, 1999).The purified colonies were further screened for their cellulase activity. Pure cultures of bacterial colonies were transferred individually on CMC agar plates. After incubation, the plates were flooded with $1 \%$ congored and the plates were allowed to stand for $20 \mathrm{~min}$ at room temperature. Then the plates were thoroughly washed with $1 \mathrm{M}$ Sodium chloride solution. A clear zone was evident around the growing colonies of cellulase positive cultures against the dark red background, the unreacted cellulose taking up the stain while the hydrolyzed portion remain colourless. The contrast was further enhanced by treating the plates with $5 \%$ acetic acid for 1 to 2 minutes and then washed off the excess acid with distilled water. Then those bacteria that were of good clearance beyond the area of growth were selected for further studies as potential cellulase secretors. The isolated bacterial colonies were further identified as Cellulomonas, Bacillus and Micrococcus spp. These three bacterial cultures were selected for estimation of extracellular cellulase - endoglucanase enzyme secretion.

\section{Inoculum preparation}

A pure culture of Bacillus, Cellulomonas and Micrococcus spp. were maintained as stock culture, from which inocula were prepared. They were grown on CMC agar slant individually at $30^{\circ} \mathrm{C}$ for 5 days and stored at $4{ }^{\circ} \mathrm{C}$ with regular subculturing. $200 \mathrm{~mL}$ of the optimised medium with each strain from a 4 day culture was used as inoculum prepared in a $250 \mathrm{~mL}$ conical flask. The 
inoculum was shaken continuously on an environmentcontrolled incubator shaker (New Brunswick Scientific Co., USA) at $200 \mathrm{rpm}$ and $35^{\circ} \mathrm{C}$ for $24 \mathrm{~h}$ before it was used for the process.

\section{Determination of endoglucanase activity}

Endoglucanase was assayed as described by Wood and Bhat (1988). The culture broth centrifuged at 5000 rpm for $20 \mathrm{~min}$ at $4{ }^{\circ} \mathrm{C}$ and the supernatant served as the enzyme source. The enzyme solution was added to $0.5 \mathrm{ml}$ of $1 \%$ carbohydrate (coir powder) substrate taken in $50 \mathrm{mM}$ sodium citrate buffer $(\mathrm{pH} 7)$. After incubation at $40{ }^{\circ} \mathrm{C}$ for $30 \mathrm{~min}$, the reaction was stopped by the addition of $1 \mathrm{ml}$ dinitrosalicylic acid reagent. After 5 minutes in a boiling water bath and quick cooling to room temperature, the degree of enzymatic hydrolysis of the cellulose was determined spectrophotometrically (UV-Vis Spectrophotometer, Techomp Scientific Equipment Ltd., Canada) by measuring the absorbance at $540 \mathrm{~nm}$. The unit of enzymeactivity was expressed as the amount of enzyme required to release $1 \mu \mathrm{mol}$ of reducing sugars as glucose equivalent $\mathrm{min} / \mathrm{g}$ of the enzyme sample.

Table 1: Microscopic examination and biochemical reaction of bacterial population isolated from coir retting effluents

\begin{tabular}{lccc}
\multicolumn{1}{c}{$\begin{array}{c}\text { Microscopic and } \\
\text { Biochemical } \\
\text { Examinations }\end{array}$} & A & B & C \\
\hline Microscopic Examination & & & \\
a. Gram staining & + rod & + rod & + cocci \\
b. Motility Test & + & + & - \\
Biochemical Reaction & & & \\
a. Indole production test & - & - & - \\
b. Methyl red test & - & + & - \\
c. Voges-Proskauer test & - & + & - \\
d. Citrate utilisation test & - & + & - \\
e. Starch hydrolysis test & + & + & - \\
f. Gelatin hydrolysis test & + & + & - \\
g. Oxidation Fermen. test & & & \\
i. Glucose fermentation & - & - & + \\
ii. Sucrose fermentation & - & - & - \\
iii. Lactose fermentation & + & + & - \\
h. Catalase test & + & + & + \\
i. Nitrate reduction test & + & + & + \\
& & & \\
\hline
\end{tabular}

\section{Optimization of production parameters}

For the effect of $\mathrm{pH}$, aliquots of the enzyme solution were incubated with $500 \mu$ l of different concentrations $(0.5,0.1,1.5$ and $2.0 \%)$ of carbohydrate substrate (coir powder) at $37{ }^{\circ} \mathrm{C}$ at different $\mathrm{pH}$ values (pH 5 and 6 using $50 \mathrm{mM}$ sodium citrate; $\mathrm{pH} 7$ uisng $50 \mathrm{mM}$ sodium phosphate and $\mathrm{pH} 8$ and 9 using $50 \mathrm{mM}$ Tris/ $\mathrm{HCl}$ ). The reactions were stopped after $30 \mathrm{~min}$ by adding dinitrosalicylic acid reagent and the activities were assayed as described above. The temperature optimum for the endoglucanase was investigated with different concentrations $(0.5,0.1,1.5$ and $2.0 \%)$ of carbohydrate substrate (coir powder), in $50 \mathrm{mM}$ sodium citrate buffer ( $\mathrm{pH} 7)$, were incubated for 30 minutes at 4 different temperatures in the range $20,30,40$ and $50{ }^{\circ} \mathrm{C}$. The reducing ends formed were determined using the dinitrosalicylic acid reagent as described above.

\section{Statistical analysis}

All experiments were performed in triplicate. The results obtained in the present study were analyzed through Two-way ANOVA test following Zar (1974).

\section{RESULTS}

Based on the microscopic examination, physical and biochemical reactions, three different cellulosedegrading bacterial genera such as Cellulomonas, Bacillus and Micrococcus spp. were identified from coir retting effluent (Table 1). All the three bacterial strains were characterized for their ability to produce endoglucanase enzymes against coconut fibre powder as a carbon substrate and optimized their enzyme production with various growth factors such as substrate concentration, $\mathrm{pH}$ and temperature.

\section{Effect of pH on endoglucanase enzyme activity \\ a. Cellulomonas spp.}

The endoglucanase enzyme activity by Cellulomonas sp at $0.5 \%$ substrate concentration at varying $\mathrm{pH}$ level showed that the activity was increased from $\mathrm{pH} 5$ to 7 $(0.0087,0.0142$ and $0.0172 \mathrm{U} / \mathrm{mL})$. Further increase in $\mathrm{pH}$ level to 8 and 9 resulted in considerable decrease in enzyme activity $(0.0097$ and $0.0083 \mathrm{U} / \mathrm{mL})$. Similar trend was observed at $1 \%$ substrate concentration, i.e. the maximum activity of $0.024 \mathrm{U} / \mathrm{mL}$ at $\mathrm{pH}$ 7. In $1.5 \%$ substrate concentration, the enzyme activity was 0.0331 $\mathrm{U} / \mathrm{mL}$ at $\mathrm{pH} 5,0.041 \mathrm{U} / \mathrm{mL}$ at $\mathrm{pH} 6,0.081 \mathrm{U} / \mathrm{mL}$ at $\mathrm{pH}$, $0.047 \mathrm{U} / \mathrm{mL}$ at $\mathrm{pH} 8$ and $0.031 \mathrm{U} / \mathrm{mL}$ at $\mathrm{pH}$. In $2 \%$ substrate concentration also, the endoglucanase enzyme activity showed by Cellulomonas spp. was minimum at $\mathrm{pH} 5(0.0125 \mathrm{U} / \mathrm{mL})$ and maximum $(0.047 \mathrm{U} /$ $\mathrm{mL}$ ) at $\mathrm{pH} 7$ (Fig. 1). Among the four different substrate concentrations, the enzyme activity was more in $1.5 \%$ substrate concentration. Statistical analysis by two 
way ANOVA on endoglucanase enzyme activity by Cellulomonas sp. revealed that the variation due to substrate concentration as well as $\mathrm{pH}$ level were statistically significant $(\mathrm{F}=18.553 ; \mathrm{P}<0.0001$ and $\mathrm{F}=$ 6.239; $\mathrm{P}<0.05)$. Further it also reveled that the influence of substrate concentration on endoglucanase activity was more than that of the influence exerts by variation in $\mathrm{pH}$.

\section{b. Bacillus spp.}

The endoglucanase enzyme activity by Bacillus spp. at $0.5 \%$ substrate concentration was much higher $(0.0165 \mathrm{U} / \mathrm{mL})$ on neutral $\mathrm{pH} 7$; whereas it was less in other tested $\mathrm{pH}$ levels. Likewise at $1 \%$ substrate concentration, the enzyme activity was minimum at $\mathrm{pH}$ $5(0.0146 \mathrm{U} / \mathrm{mL})$ and it showed a marginal increase $(0.0180$ and $0.0210 \mathrm{U} / \mathrm{mL})$ at $\mathrm{pH} 6$ and 7 . Further this activity was greatly reduced to 0.0134 and $0.0132 \mathrm{U} / \mathrm{mL}$ at $\mathrm{pH} 8$ and 9 respectively. In $1.5 \%$ substrate concentration, the enzyme activity was lesser at $\mathrm{pH} 5$ $(0.0243 \mathrm{U} / \mathrm{mL})$ and it was $0.041 \mathrm{U} / \mathrm{mL}$ at $\mathrm{pH} 7$ and at $\mathrm{pH}$ 8 and 9, it gradually decreased to 0.025 and $0.021 \mathrm{U} / \mathrm{mL}$. The trend observed for the endoglucanase enzyme activity by Bacillus spp. at $2.0 \%$ substrate concentration was more or less same with that of observed for $0.5,1.0$ and $1.5 \%$ substrate concentrations (Fig. 1). Among the four different substrate concentrations tested, the activity was more at $1.5 \%$. The two-way ANOVA revealed that the endoglucanase enzyme activity due to varying substrate concentrations was statistically more significant $(\mathrm{F}=$ 22.477; $\mathrm{P}<0.0001)$ than the variation due to different pH levels ( $\mathrm{F}=5.703 ; \mathrm{P}<0.005)$.

\section{c. Micrococcus spp.}

The endoglucanase activity shown by Micrococcus sp. inferred that, at $0.5 \%$ substrate level, the enzyme activity was $0.0071 \mathrm{U} / \mathrm{mL}$ in $\mathrm{pH} 5$ and it increased to 0.0091 and $0.0121 \mathrm{U} / \mathrm{mL}$ at $\mathrm{pH} 6$ and 7 . Then it was decreased to 0.0073 and $0.0037 \mathrm{U} / \mathrm{mL}$ at $\mathrm{pH} 8$ and 9 . Similar trend was obtained in other substrate concentrations also (1, 1.5 and 2.0\%) (Fig. 1). The twoway ANOVA revealed that the endoglucanase enzyme activity by Micrococcus spp. due to the variation of substrate concentrations as well as due to the variation of $\mathrm{pH}$ level were statistically more significant ( $\mathrm{F}=$ 11.116; $\mathrm{P}<0.005$ and $\mathrm{F}=19.671 ; \mathrm{P}<0.0001)$.

\section{Effect of temperature on endoglucanase enzyme activity \\ a. Cellulomonas spp.}

At $0.5 \%$ substrate concentration, the enzyme activity was more at $40^{\circ} \mathrm{C}(0.0336 \mathrm{U} / \mathrm{mL})$, whereas it was less in $20^{\circ} \mathrm{C}(0.0151 \mathrm{U} / \mathrm{mL}), 30^{\circ} \mathrm{C}(0.0172 \mathrm{U} / \mathrm{mL})$ and $50^{\circ} \mathrm{C}$ $(0.0154 \mathrm{U} / \mathrm{mL})$. In $1 \%$ substrate concentration also, the enzyme activity was more at $40^{\circ} \mathrm{C}(0.0740 \mathrm{U} / \mathrm{mL})$, and less $(0.025,0.039$ and $0.041 \mathrm{U} / \mathrm{mL})$ at 20,30 and $50^{\circ} \mathrm{C}$. In the case of 1.5 and $2 \%$ substrate concentrations, the enzyme activity was 0.0723 and $0.0360 \mathrm{U} / \mathrm{mL}$ at $20^{\circ} \mathrm{C}$, 0.0710 and $0.0430 \mathrm{U} / \mathrm{mL}$ at $30^{\circ} \mathrm{C}, 0.0920$ and $0.0490 \mathrm{U} /$ $\mathrm{mL}$ at $40^{\circ} \mathrm{C}$ and 0.0830 and $0.0490 \mathrm{U} / \mathrm{mL}$ at $50^{\circ} \mathrm{C}$ (Fig. 2). The statistical analysis (Two-way ANOVA) revealed that the enzyme activity due to different substrate concentrations and due to various temperatures were statistically more significant $(\mathrm{F}=39.015 ; \mathrm{P}<0.0001$ and $\mathrm{F}=7.587$; $\mathrm{P}<0.05$ ).

\section{b. Bacillus spp.}

The enzyme activity by Bacillus spp. at $0.5 \%$ substrate concentration showed maximum of $0.0190 \mathrm{U} / \mathrm{mL}$ at 40 ${ }^{\circ} \mathrm{C}$, whereas it was less $(0.0154,0.020$ and $0.0197 \mathrm{U} / \mathrm{mL})$ at 20,30 and $50{ }^{\circ} \mathrm{C}$ temperatures respectively. In $1 \%$ substrate concentration, the enzyme activity was 0.0194 $\mathrm{U} / \mathrm{mL}$ at $20^{\circ} \mathrm{C}$ and it increased to 0.025 and $0.0351 \mathrm{U} / \mathrm{mL}$ at 30 and $40{ }^{\circ} \mathrm{C}$, respectively, again the activity decreased to $0.0241 \mathrm{U} / \mathrm{mL}$ at $50{ }^{\circ} \mathrm{C}$. In 1.5 and $2 \%$ substrate concentrations, more or less a similar trend was observed in the activity of endoglucanase (Fig. 2). The statistical test carried out by two-way ANOVA revealed that the endoglucanase enzyme activity due to the variation of substrate concentrations was statistically more significant $(\mathrm{F}=14.018 ; \mathrm{P}<0.005)$ than the variation due to temperature $(\mathrm{F}=4.130 ; \mathrm{P}<0.05)$.

\section{c. Micrococcus spp.}

The enzyme activity in Micrococcus spp. at $20^{\circ} \mathrm{C}$ was $0.0122,0.161,0.0181$ and $0.0139 \mathrm{U} / \mathrm{mL}$ in the tested substrate concentrations ( 0.5 to $2.0 \%$ ). Similarly at 30 ${ }^{\circ} \mathrm{C}$, it ranged from 0.0131 to $0.0194 \mathrm{U} / \mathrm{mL}$ at 0.5 to $2 \%$ substrate concentrations. But at $40{ }^{\circ} \mathrm{C}$, the enzyme activity was little high (0.0152, $0.0182,0.0274$ and 0.0241 $\mathrm{U} / \mathrm{mL}$ ) at the tested substrate concentrations ( 0.5 to $2.0 \%$ ). In $50^{\circ} \mathrm{C}$ also, the enzyme activity was less than that of recorded at $40^{\circ} \mathrm{C}$ and it ranged from 0.0121 to $0.0231 \mathrm{U} / \mathrm{mL}$ at the tested substrate concentrations ( 0.5 to $2.0 \%$ ) (Fig. 2). Among the four different temperatures tested, $40^{\circ} \mathrm{C}$ is the optimum temperature for maximum enzyme activity. Similarly $1.5 \%$ substrate concentration 
Effect of different growth...

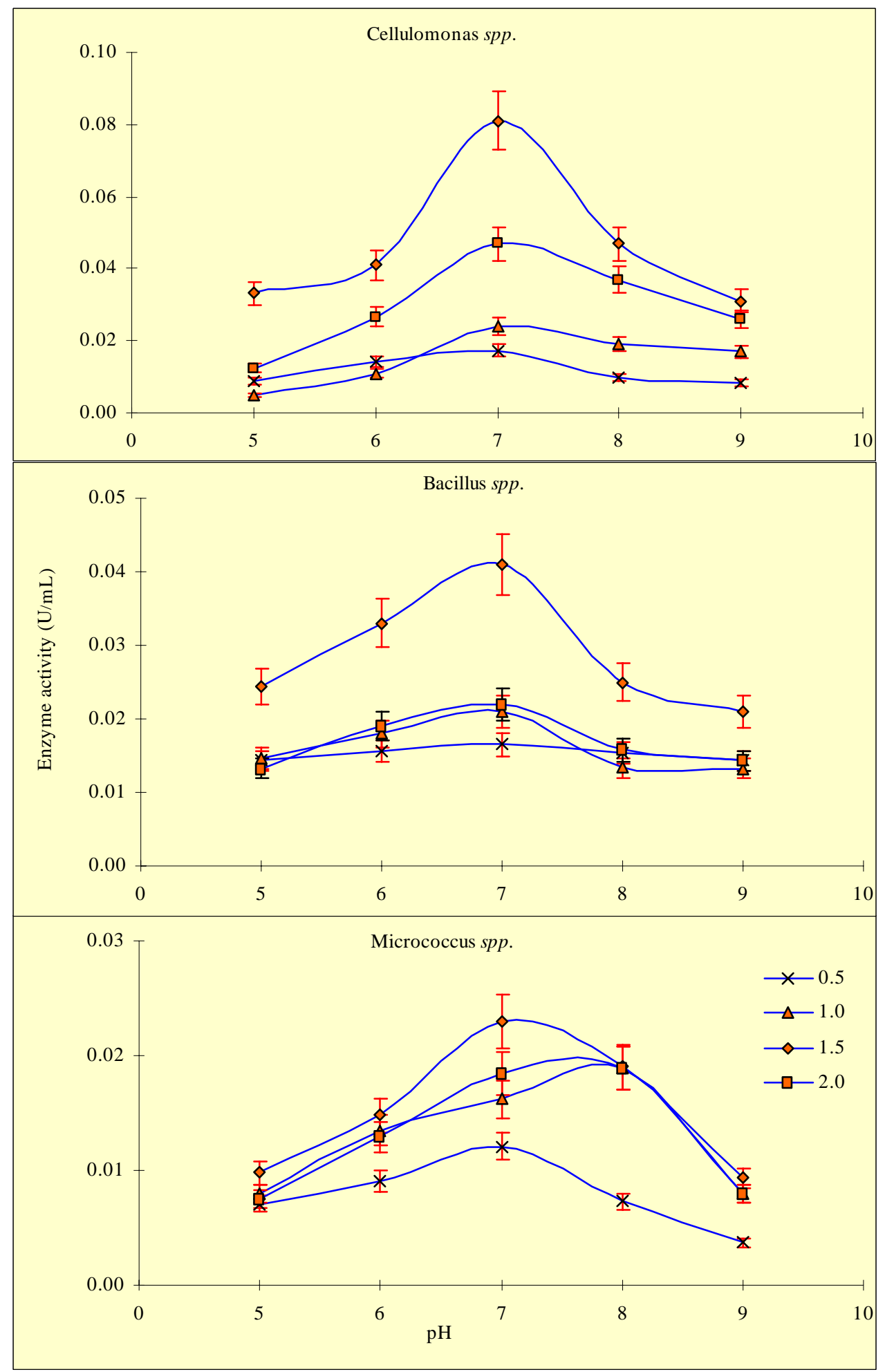

Fig. 1 : Endoglucanase enzyme activity (U/mL) by using various concentrations $(0.5-2 \%)$ of substrate at different $\mathrm{pH}(5-9)$ by three different bacteria 
G. Immanuel, et al.

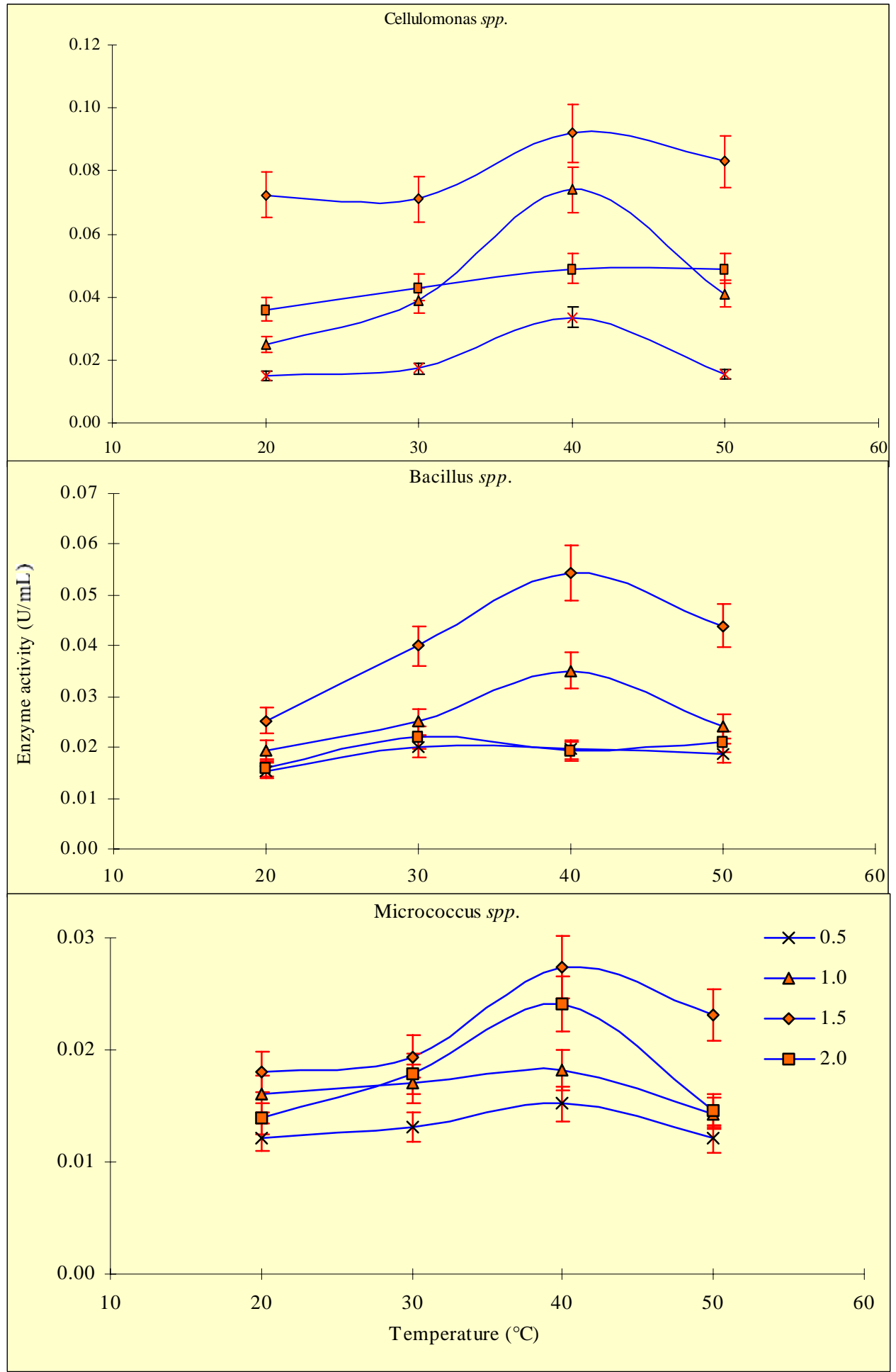

Fig. 2 : Endoglucanase enzyme activity $(\mathrm{U} / \mathrm{mL})$ by using various concentrations $(0.5-2 \%)$ of substrate at different temperature $\left(20-50{ }^{\circ} \mathrm{C}\right)$ by three different bacteria 
was also found to be optimum for enzyme activity. The analysis of variance (Two- way) revealed that the endogluconase enzyme activity due to the substrate concentrations was statistically significant $(\mathrm{F}=11.223$; $\mathrm{P}<0.05)$. But enzyme activity due to the variation in temperature was not statistically significant $(\mathrm{F}=6.272$; $\mathrm{P}>0.01)$.

\section{DISCUSSION AND CONCLUSION}

In the present study, three bacterial strains such as Cellulomonas, Bacillus and Micrococcus spp. were identified for their ability to produce endoglucanase enzyme against pretreated coir fibre powder, isolated from coir retting effluent. The increase of cellulase activity was studied by optimization of enzyme production at various environmental factors such as temperature and $\mathrm{pH}$.

Cellulose serves as a carbon source for the growth of bacteria and also as an inducer for the production of cellulase. Some previous studies reported that the agricultural wastes of lignocellulosics are used as a carbohydrate source to produce commercially important products such as ethanol, glucose and single cell protein (Solomon et al., 1999). Similarly Ojumu et al., (2003) reported some lignocellulosics as carbon source for cellulase enzyme production. They reported $0.0743 \mathrm{U} / \mathrm{mL}$ of cellulase enzyme activity from sawdust and 0.0573 and $0.0502 \mathrm{U} / \mathrm{mL}$ from bagasse and corncob respectively. In the present study also various concentrations ( 0.5 - $2 \%)$ of pretreated coir fibre powder as a carbon source was used to find out the enzyme activity. Among the tested concentrations 1.5\% substrate showed higher enzymatic activity (0.081, 0.041 and $0.023 \mathrm{U} / \mathrm{mL}$ at $\mathrm{pH} 7$ for Cellulomonas, Bacillus and Micrococcus spp. respectively). The enzyme with very low activity was accounted from much lower and higher concentrations. Similar reports from few experiments showed that the enzyme activity in Bacillus spp. was detected in cultures that contained $1 \%(\mathrm{w} / \mathrm{v})$ CMC as the growth substrate (Fukumori et al., 1985; Kawai et al., 1988; Shikata et al., 1990). In accordance with these, reports of enzyme activity by Strepetomyces spp. isolated from soil samples with various substrate (CMC) concentrations (0.5-1.5\%) showed that maximum activity was achieved at $1 \%$ substrate concentration (Hankin and Anagnostakis, 1977). But some new studies on Sinorhizobium fredii, reported that $0.5 \%$ of substrate concentration showed better enzyme activity (Po-Jui Chen et al., 2004). Robson and Chambliss (1984) reported that the presence of metabolized carbohydrates in the growth medium stimulated the production of cellulolytic activity.

The enzyme hydrolyzes substrate in the $\mathrm{pH}$ range of 4.0 to 9.0, with maximum activity occurring at $\mathrm{pH} 7.0$. The enzyme maintained their stability over a wide range of $\mathrm{pH}$ 6-8, but it had maximum activity at $\mathrm{pH}$ 7. GoKhan Coral et al. (2002) reported that maximum CMCase activity was recorded at $\mathrm{pH} 7.5$ by Aspergillus niger (Z10 wild type strain) when among the tested $\mathrm{pH}$ range between 4-9. Similarly the optimal condition of pH 6-7 for maximum enzyme activity in A. niger also reported by Akiba et al., (1995). Alkaline $\mathrm{pH}$ value ( $\mathrm{pH} 12$ ) also affected the enzyme activity in Bacillus spp. by $50 \%$ and furthermore, the CMCase in Bacillus spp. is alkaline, which renders it suitable for use as an effective laundry detergent additive (Khyami-Horani, 1991). Some previous studies from Garcia-Martinez et al. (1980) and Prasetson and Doelle (1987) reported that pH 7 appears to play a decisive role in cellulose digestion for maximum enzyme production by Clostridium thermocellum and Cellulomonas spp. respectively.

Like $\mathrm{pH}$, temperature is also an important factor that influences the production of enzyme. In the present study, the optimum temperature was found to be around $40{ }^{\circ} \mathrm{C}$ and the enzyme activity of $0.092,0.0543$ and 0.0274 $\mathrm{U} / \mathrm{mL}$ at $\mathrm{pH} 7$ and $1.5 \%$ substrate concentration were recorded for Cellulomonas, Bacillus and Micrococcus spps. respectively. Gokhan Coral et al., (2002) reported, the optimum temperature for CMCase activity was 40 ${ }^{\circ} \mathrm{C}$ in A. niger Z10 strain. But these values were lower than that of the commercial cellulase production temperature of $60{ }^{\circ} \mathrm{C}$ and the optimum temperature required for enzyme production by bacterial strains as well as fungal strains are entirely differed. Cellulase activities from Trichoderma sp. and other mesophilic cellulolytic fungi are at their optimum when assayed at about $50^{\circ} \mathrm{C}$ (Mandels et al., 1974; Tangnu et al., 1981; Kawamori et al., 1987). However, the optimum temperature for Trichoderma sp. A-001 was at least 10 ${ }^{\circ} \mathrm{C}$ higher than the others (Durand et al. 1984; Margaritus and Merchant, 1986).

In conclusion, the present study revealed that coconut fibre powder is one of the best carbohydrate substrates for endogluconase enzyme production by the organisms viz. Cellulomonas, Bacillus and Microccocus spp. The organisms were readily utilized this substrate and the present study confirmed that 40 ${ }^{\circ} \mathrm{C}$ is the optimum temperature at $1.5 \%$ substrate concentration with neutral $\mathrm{pH}$ for higher endoglucanase activity. 


\section{REFERENCES}

Akiba, S., Kimura, Y., Yamamoto, K. and Kumagap, H., (1995). Purification and characterization of a protease-resistant cellulase from Aspergillus niger. J. Fermen. Bioengin., 79, 125-132.

Brown, J. A., Collin, S. A. and Wood, T. M., (1987). Development of a medium for high cellulase, xylanase and $\beta$-glucosidase production by a mutant strain (NTG 1116) of the cellulolytic fungus Penicillium pinophilium. Enzyme Micro. Tech., 5, 425-429.

Cailliex, C., Benoit, E., Gelhaye, H., Petitdemange, H. and Raval, G., (1992). Solubilization of Cellulose by mesophilic cellulolytic Clostridia isolated from a municipal solid-water diester. Bioresource Technology, Elsevier Science Publisher Ltd., England, 77-483.

Cappuccino, J. G. and Sherman, N., (1999). Microbiology- A laboratory manual. $4^{\text {th. }}$ edition, Addision Wesley Longman, Inc. Sydney, Australia, 477.

Durand, H., Sovcaille and Tiraby, G., (1984). Comparative study of cellulase and hemi cellulases

from four fungi. Enzyme Micro. Tech., 6, 175-180.

Fukumori, F., Kudo, T. and Horikoshi, K., (1985). Purification and properties of a cellulase from alkalophilic Bacillus sp. No. 1139. J. Gen. Microbiol., 131, 129-135.

Garcia-Martinez, D. V., Shinmyo, A., Madia, A. and Deman, A. L., (1980)., Studies on cellulase production by Clostridium thermocellum. Europ. J. Appl. Microbiol. Biotechnol., 9, 189-197.

Gharpuray, M. M., Lee, Y. H. and Fan, L. T., (1983)., Structural modification of lignocellulosics by treatment to enhance enzymatic hydrolysis. Biotechnol. Bioeng., 25, 157-172.

Gokhale, D. V., Soo-Han, E., Srinivasan, V. R. and Deobagkar, D. N., (1984)., Transfer of DNA coding for cellulases from Cellulomonas sp. to Bacillus subtilis by protoplast fusion. Biotechnol. Lett., 6, 627-632.

Gokhan Coral, G., Burhan, A. N., Naldi, M. and Hatice, G. V., (2002)., Some Properties of Crude Carboxymethyl Cellulase of Aspergillus nigerZ10 Wild-Type Strain. Turkish Journal of Biology, 26, 209-213.

Greaves, H., (1971)., The effect of substrate availability on cellulolytic enzyme production by selected wood rotting microorganisms. Australian J. Bio. Sci., 24, 1167-1180.

Haggett, K. D., Choi, W. Y. and Dunn, N. W., (1978)., Mutants of Cellulomons, which produce increased levels of $\beta$ "glucosidase. Europ. J. Appl. Microbiol. Biotechnol., 6, $189-191$.

Hankin, L. and Anagnostakis, S., (1977)., Solid media containing Carboxy methyl cellulose to detect CM cellulase activity of Microorganisms. J. Gen. Microbiol., 98, 109 -115.

Hoffman, R. M. and Wood, T. M., (1985)., Isolation and partial characterization of a mutant of Penicillium for the saccharification of straw. Biotechnol. Bioeng., 27, 81-85.

Kansoh, A. L., Essam, S. A. and Zeinat, A. N., (1999)., Biodegradation and utilization of bagasse with Trichoderma reesei. Polym. Degrad. Stab., 62, 273-278.

Kawai, S. H., Okoshi, K., Ozaki, S., Shikata, K. A. and Ito, S., (1988). Neutrophilic Bacillus strain, KSM-522, that produces an alkaline carboxymethyl cellulase. Agri. Bio. Chem., 52, 1425-1431.

Kawamori, M., Takaymma, K. and Takasawa, S., (1987). Production of cellulase by a thermophilic fungus Thermoascus aurantiacus A-131. Agri. Bio. Chem., 51, 647654.

Khyami-Horani, H., (1991). Characterization and Cellulase Synthesis. In Some Thermotolerant Bacilli from Jordan. PhD Thesis. University of Heriot-Watt, Edinburgh, Scotland.

Lakshmikant, K. and Mathur, S. N., (1990). Cellulolytic activities of Cheatomium globosum on different cellulosic substrates. W. J. Microbiol. Biotech., 11, 23-26.

Leschine, S. B. and Canale, E., (1983). Parola. Mesphilic cellulolytic Clostridia from fresh water environments. Appl. Environ. Microbiol., 46, 728-737.

Mandels, M., Hontz, L. and Nystron, J., (1974). Enzymatic hydrolysis of waste cellulose. Biotech. Bioengin., 16, 1471493.

Mandels, M., (1975). Microbial sources of cellulases, BBiotech. Bioengin., 5, 81-105.

Madden, R. H., Bryder, M. J. and Poole, N. J., (1982). Isolation and characterisation of an anaerobic, cellulolytic bacterium Clostridium papoyrosolvens sp. Nov. acellulolytic thermophile. Int. J. Sys. Bacter., 32, 87-91.

Madden, R. H., (1983). Isolation and characterisation of Clostridium stereorurium sp. Nov. a cellulolytic thermophile. IInt. J. Sys. Bacter., 33, 837-840.

Margaritis, A. and Merchant, R. F., (1986). Optimization of fermentation conditions for thermostable cellulase production by Thiolana terressus. J. Indust. Microbiol., 1, 149-150.

Nakamura, K. and Kppamura,. K., (1982). Isolation and identification of crystalline cellulose hydrolyzing bacterium and its enzymatic properties. J. Ferment. Technol., 60 (4), 343 - 348.

Ojumu, T., Solomon, V., Bamidele, O., Betiku, E., Layokun S. K. and Amigun, B., (2003). Cellulase Production by Aspergillus flavus Linn Isolate NSPR 101 fermented in sawdust, bagasse and corncob. African J. Biotechnol., 2 (6), 150-152.

O’Neill, G., Goh, S. H., Warren, R. A., Kilburn D. G. and Miller, R. C., (1986). Structure of the gene encoding the exoglucanase of Cellulomonas fimi. Gene, 44 (2-3), 325330.

Palop, M. L., Valles, S., Pinaga, F. and Flors, A., (1989). Isolation and characterization of an anaerobic, cellulolytic bacterium, Clostridium celerecrescens Sp. Int. J. Sys. Bacteriol., 39, 68-71.

Petidemange, E., Caillet, F., Giallo, J. and Caudin, C., (1984). Clostidium cellulolyticum sp. novo, a cellulolytic 
mesophilic species from decayed grass. Int. J. Sys. Bacteriol., 34, 155-159.

Po-Jui Chen, W., Tao-Chun, C., Yao-Tsung and Liang, P. L., (2004). Purification and characterization of carboxymethyl cellulase from Sinorhizobium fredii, Bot.Bull.Acad.Sin., 45, 111-118.

Prasetsan, P., Doelle, H. W., (1987). Nutrient optimization for cellulase biosynthesis by a newly isolated Cellulomonas sp. Mircen. J. 3, 33-44.

Robson, L. M. and Chambliss, G. H., (1984). Characterization of the cellulolytic activity of a Bacillus isolate. Appl. Environ. Microbiol., 47, 1039-1046.

Sexana, S., Bahadur, J. and Varma, A., (1993). Cellulose and hemi-cellulose degrading bacteria from termite gut and mound soils of India. Int. J. Microbiol., 33 (1), 55-60.

Shen, H., Meinke, A., Tomme, P., Damude, H. G., Kwan, E., Kilburn, D. G., Miller, R. C., Warren Jr, R. A. J. and Gilkes, N. R., (1995). Cellulomonas fimi cellobiohydrolases In: J. N. Saddler and M. H. Penner (Eds.) Enzymatic Degradation of Insoluble Polysaccharides American Chem. Society Washington DC,.174-196.

Shikata, S., Saeki, K., Okoshi, H., Yoshimatsu, T., Ozaki, K., Kawai, S. and Ito, S., (1990). Alkaline cellulase for laundry detergents: production by alkalophilic strains of Bacillus and some properties of crude enzymes. Agri. Bio. Chem., 52, 91-96.

Sharma, V. K. and Hobson, P. N., (1985). Isolation and cellulolytic activities of bacteria from a cattle waste anaerobic digester and the properties of some Clostridium species. Agri. Was., 14, 173-196.
Skinner, F. A., (1960). The isolation of anaerobic cellulose decomposing bacteria from soil. J. Gen. Microbiol., 22, 539554.

Sleat, R. and Mah, R. A., (1984). Clostridium populeti sp. Novo. a cellulolytic species from a woody- biomass digester. J. Sys. Bacteriol., 35, 160-163.

Solomon, B. O., Amigun, B., Betiku, E., Ojumu, T. and Layokun, S. K., (1999). Optimization of Cellulase Production by Aspergillus flavus Linn Isolate NSPR 101 Grown on Bagasse. JNSChE, 16, 61-68.

Stewart, B. and Leatherwood, J. M., (1976). Derepressed synthesis of cellulase by Cellulomonas. J. Bacteriol., 128, 609-615.

Tangnu, S. K., Blanch, H. W. and Wilke, C. R., (1981). Enhanced production of cellulase, hemicellulase and $\beta$-glucosidase by Trichoderma reesei. Biotech. Bioengin., 23, 1837- 1849.

Whittle, D. J., Kilburn, D. G., Warren, R. A. and Miller, R. C., (1982). Molecular cloning of a Cellulomonas fimi cellulose gene in Escherichia coli. Gene, 17(2), 139-145.

Wood, T. M. and Bha, K. M., (1988). Methods for measuring cellulase activities. Method. Enzymol., 160, 87-112.

Zar, J. H., (1974). Bio-Statistical Analysis, Prentice Hall, New Jersey, 620. 


\section{AUTHOR (S) BIOSKETCHES}

Immanuel, G., M.Sc., Ph.D., Senior lecturer in the Department of Marine Biotechnology, Centre for Marine Science and Technology, M.S. University, Rajakkamangalam- 629502, Kanyakumari District, Tamilnadu, India.E.mail:__immas@yahoo.com

Danusha, R., Ph.D., Scholar in the Department of Microbiology, Centre for Marine Science and Technology, M.S. University, Rajakkamangalam-629502, Kanyakumari District, Tamilnadu, India.

Prema, P., M.Sc., M.Phil., Ph.D., Lecturer in the Department of Microbiology, Centre for Marine Science and Technology, M.S. University, Rajakkamangalam- 629502, Kanyakumari District, Tamilnadu, India. E.mail:prema_drprema@yahoo.com

Palavesam, A., M.Sc., M.Phil., Ph.D., Reader in the Department of Marine Biotechnology, Centre for Marine Science and Technology, M.S. University, Rajakkamangalam- 629502, Kanyakumari District, Tamilnadu, India.E.mail:plavesh@yahoo.com

\section{This article should be referenced as follows:}

Immanuel, G., Dhanusha, R., Prema, P. and Palavesam, A., (2006). Effect of different growth parameters on endoglucanase enzyme activity by bacteria isolated from coir retting effluents of estuarine environment. Int. J. Environ. Sci. Tech., 3 (1), 25-34. 